$14^{\text {th }}$ Conf. Agric. Develop. Res., Fac. of Agric., Ain Shams

Univ., March, 2019., Cairo, Egypt

Special Issue, 27(1), 869 - 875, 2019

Website: http://strategy-plan.asu.edu.eg/AUJASCl/

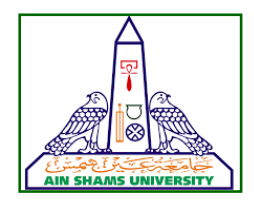

\title{
COMPARATIVE STUDIES ON SOME PRODUCTIVE TRAITS AND GENETIC DIVERSITY OF TWO LOCAL STRAINS OF DUCKS: SUDANI AND DOMYATI
}

\author{
Madian $^{1}$. H.A., Mahrous ${ }^{2}$ M.Y., Lamiaa M. Radwan ${ }^{2 \star}$, Badaw ${ }^{1}$ Y.K. \\ and Zein El-Dein ${ }^{2}, \mathrm{~A}$. \\ 1. Animal Production Research institute, Agriculture Research Center, Giza, Egypt \\ 2. Poultry Production Dept., Fac. of Agric., Ain Shams Univ., P.O. Box 68, Hadyek Shoubra \\ 11241, Cairo, Egypt
}

*Corresponding author: Lamia_radwan@agr.asu.edu.eg

Received 9 September, 2018, $\quad$ Accepted 2 October, 2018

\begin{abstract}
The present study aimed to investigate the Genetic Diversity and productive Performance for Some Duck Local strains (sudani and domiaty) using Microsatellite genotyping analysis. From the hatched duck chicks, fifty day old ones were taken at random from each strain and reared under the same environmental, managerial and hygienic conditions from one day old until they aged 12 weeks (marketing age). The comparison was held between the two local duck strains for the following traits: Body weight and body measurements measured biweekly from day old until 12 weeks (pooled sex). Body measurements (shank length, keel length and body circumference) measured at $4,8,12$ weeks of age for each strain. All chicks provided reared on floor pens, feed and water were provided ad-libitum all ducks chicks fed on two types of rations: A starter ration (from 0-4wks) and A finisher one (from 5-12 wks). The results indicated that There were significant differences in Body weight at all studied ages between Sudani and Domiaty strains (except at 2, 6 wks.) in hatching the average body weight of the Sudanese strain was $40.80 \mathrm{~g}$ however it was $34.12 \mathrm{~g}$ for the domyati strain, At 4 weeks age, the average body weight of Sudanese strain was $617.21 \mathrm{~g}$ while it was $446.38 \mathrm{~g}$ for the domyati strain, At 8 weeks age, the average body weight of Sudanese strain was $1490.90 \mathrm{~g}$ since it was $1235.98 \mathrm{~g}$ for the domyati strain and At 12 weeks age, the average
\end{abstract}

body weight of Sudanese strain was $2211.0 \mathrm{~g}$ while was $1691.88 \mathrm{~g}$ for the domyati strain. Also Body measurements of duck during early periods of growth (aged 4, 8 and 12 weeks) was At 4 wks age there were no significant differences between the two strains, At the age of 8 wks, the same trend was observed concerning the absence of the significant differences between strains and At the age of 12 wks, there were significant differences between the two strains of the breast circumference only where the superiority was recorded for the domyati strain, This may be reflected the genetic differences between the two strains. The results appeared that the PIC (polymorphic information content) of most microsatellite sites was lower than 0.5 . This means that the selected microsatellite loci had a1ow diversity and can reflect the genetic relationship among Sudani and Domiaty populations. This assured that both sudani and domyati populations could be considered as a near populations on a molecular level.

Key words: Microsatellite analysis, Ducks performance

\section{INTRODUCTION}

Egyptian Ancestors have known well waterfowl production since thousands years ago. Ducks production occupied the second rank after chicken production. Waterfowl plays an important role in poultry industry especially in Egypt. Ducks took an 
increased attention in the last years in Egypt for production of both meat and hatching eggs. In recent years many researchers gave more attention to increase meat production (Awad et al 2009 and Kout El-kloub et al 2010).

Ducks are important source for meat, egg and fatty liver and the demand on duck meat steady increased. In addition ducks had natural immunity against some chicken infection diseases such as newcasttel, marks and leucosis. Breeding needs information on genetic background about ducks, particularly the genetic variation. With the recent advances in techniques in molecular genetics, the detailed genetic information of animals is available with high accuracy compared to the information obtained by pedigree relationship and trait phenotypes. Such techniques have been successfully employed to address the genetic variation and, in turn, the genetic diversity among different populations, which can help in breeding programs. The association between molecular techniques and conventional animal breeding methods to identify animals with higher genetic potential tends to maximize the genetic gain for the traits of interest (Schmidt et al 2000).

Molecular techniques have provided new markers for the study of genetic variation among these techniques; microsatellite has rapidly become the favorite method for population genetic studies as it shows advantages over other methods, particularly, in conservation projects. Microsatellites are widely distributed in the genome, and thus these exhibit a high degree of polymorphism among breeds and even individuals. The observed genetic diversities arise from the consequence of genetic drift and mutation. Several studies of genetic relationships between duck breeds using the microsatellite method were reported previously

The aim of this study is to evaluate the differences both in productive traits and also the genetic diversity in the populations of Sudani and domyati (local) strains under the Egyptian environmental conditions.

\section{MATERIAL AND METHODS}

This experiment was carried out at El-Serw Research Station which belongs to Animal Production Research Institute, Agricultural Research Center, Ministry of Agricultural and the laboratory part of this work was done in the laboratories of Fac. of Agri., Ain-Shams University.
From the hatched duck chicks, fifty day old ones were taken at random from each strain and reared under the same environmental, managerial and hygienic conditions from one day old until they aged 12 weeks (marketing age).All chicks provided reared on floor pens, feed, water and normal condition was provided ad-libitum all ducks chicks fed on two types of ration: A starter ration (from 04wks) and $A$ finisher (from 5-12 wks). Composition and chemical analysis of experimental diets are present in Table (1).

Table 1. Composition of the rations

\begin{tabular}{|l|c|c|c|}
\hline \multirow{2}{*}{\multicolumn{1}{|c|}{ Components }} & \multicolumn{3}{c|}{$\%$} \\
\cline { 2 - 4 } & Starter & Grower & Layer \\
\hline Yellow corn & 65.00 & 63.00 & 66.00 \\
Soya bean meal (44\%) & 30.45 & 15.50 & 21.30 \\
Wheat bran & 0.65 & 17.78 & 2.94 \\
Di-caphos. & 1.80 & 1.25 & 1.50 \\
Calcium carbonat (Ca Co 3$)$ & 1.40 & 1.80 & 7.60 \\
Vitamin\&minerals mixture & 0.30 & 0.30 & 0.30 \\
Sodiumchloride (Na Cl) & 0.30 & 0.30 & 0.30 \\
D.L. Methionine & 0.10 & 0.07 & 0.06 \\
Total & 100.00 & 100.00 & 100.00 \\
Crude protein \% & 19.20 & 15.20 & 15.67 \\
ME Kcal. / Kg. & 2868.00 & 2690.00 & 2746.00 \\
\hline
\end{tabular}

The comparison was held between the two duck strains for the following traits

A-Body weight and body measurements biweekly from day old until 12 weeks old (pooled sex).

B-Body measurements (shank length, keel length and body circumference) at 4,8,12 weeks of age for each strain.

\section{Statistical analysis}

It was done according to SAS, Inst. (2001) where we used one way, two way and three way ANOVA according to the number of main effects influenced the studied traits

\section{Blood samples collection and DNA isolated:}

Twelve venous blood samples were randomly taken from two duck local breed (6 samples of each strain) into $3 \mathrm{ml}$ tubes containing EDTA as an anticoagulant agent. The DNA isolated from blood samples by protocol Lougheed Genetics Laborato- 

of ducks: Sudani and Domyati

ry Manual 2005. Eleven microsatellite primers were designed of Maak et al (2000, 2003). The Table (6) appear Microtallites primers features.

Microsatellite genotyping analysis

Polymorphic information content (PIC) was calculated by formula (Botstein et al 1980); the expected $(\mathrm{He})$ and observed $(\mathrm{Ho})$ heterozygosity calculated by formal (Hedrick, 1999); effective number of alleles (E) calculated by formula (Xiao, 2002).

$P I C=1-\Sigma m i-1 P 2 i-\Sigma m-1 i-1 \sum m J-i+12 P 2 i P 2 j$

$H e=1-\Sigma m i-1 P 2 i ; H o=1-\Sigma N i j / N ; E=1-/ \Sigma m i-$ $1 P 2 i$

Where $\mathrm{m}$ was the number of the allele, and $\mathrm{Pi}$ and $\mathrm{Pj}$

Were the frequencies of the ith and the jth allele, respectively.

Allele frequencies were computed by $\mathrm{Pi}=(2$ $(\mathrm{ii})+(\mathrm{ij} 1)+(\mathrm{ij} 2)+\ldots+(\mathrm{ijn})) / 2 \mathrm{~N}$, where $\mathrm{Pi}$ was the frequency of the ith allele for which i represented the allele, while j1, j2, ... were the co-dominant alleles to $i$, and $n$ was the number of the allele.

\section{Dimensional gel electrophoresis analysis}

The blood proteins were analyzed by $2-\mathrm{DE}$ analysis using the Ettan IPGphor 3 System as described previously (Qiu et al 2012). The protein spots on analytical and preparative 2-DE gels were stainedbysilverandCoomassieBrilliantBlueG250, respectively. Subsequently, gel evaluation and data analysis were carried out using the Image Master v 7.0 program (GE Healthcare).

\section{RESULTS AND DISCUSSION}

\section{Body weight at different age}

Mean \pm SE of Body weight for both sudani and domyati ducks are presented in Table (2). There were significant differences in Body weight at all studied ages between Sudani and Domiaty strains (except 2, 6 wks was not significant). It reflects the genetic difference between strains. Similar results for Sudani and domyati body weight were reported by Farghaly and Asar (1988), Ali (2005), Awad et al (2013) and Awad et al (2014).
Table 2. Mean \pm SE of Body weight for both sudani and domyati ducks

\begin{tabular}{|c|c|c|c|}
\hline $\begin{array}{c}\text { Age } \\
\text { (week) }\end{array}$ & Sudani & Domiaty & $(\mathbf{P} \leq \mathbf{0 . 0 5})$ \\
\hline 0 & $40.80^{\mathrm{a}} \pm 0.40$ & $34.12^{\mathrm{b}} \pm 0.39$ & 0.04 \\
2 & $225.69 \pm 5.44$ & $229.98 \pm 7.82$ & $\mathrm{NS}$ \\
4 & $617.21^{\mathrm{a}} \pm 10.91$ & $446.38^{\mathrm{b}} \pm 30.11$ & 0.02 \\
6 & $951.23 \pm 20.06$ & $930.21 \pm 17.69$ & $\mathrm{NS}$ \\
8 & $1490.90^{\mathrm{a}} \pm 11.24$ & $1235.98^{\mathrm{b}} \pm 13.48$ & 0.02 \\
10 & $1851.18^{\mathrm{a}} \pm 23.10$ & $1589.13^{\mathrm{b}} \pm 23.81$ & 0.01 \\
12 & $2211.0^{\mathrm{a}} \pm 45.11$ & $1691.88^{\mathrm{b}} \pm 21.28$ & 0.001 \\
\hline
\end{tabular}

\section{Body measurements}

Mean of Body measurements for both sudani and domyati ducks are presented in Tables $(3,4$, and 5). There were significant differences in Body measurements between Sudani and Domiaty strains. Also there were significant differences between the two sexes within each strain noticed for different body measurement at all studied ages (Tables 3, 4 and 5). Shank length, keel length and breast circumstances were significantly longer in males than females, the same results reported by Fattouh (1994) and EL-Sayed (1979).

\section{Shank length measurements}

Table (3) showed that there were significant differences due to sex and occurred in shank length this trend did not exist between strains. also Sudani and Domiaty males were higher significant than Sudani and Domiaty females, although Sudani male higher than Domiaty male, also Domiaty female higher than Sudani female Nestor et al (1985) noticed that selection program to increase shank length resulted significant longer shank length, but in male only. Similar results in shank length were reported by Ali (2000), El Tehiti (2001) and Ali (2005).

\section{Keel length measurements}

Table (4) showed that The same trend noticed for shank length existed also for keel length, while both sex and age affected significantly keel length with strain did not affect this trait also sudani and domyati males were higher significant than sudani and domyati females, although. Similar results in keel length were reported by Ali (2005) and Ayman (2015) 
Table 3. Mean \pm SE of shank length $(\mathrm{cm})$ for both sudani and domyati ducks.

\begin{tabular}{|c|c|c|c|c|c|c|c|c|c|}
\hline \multirow[b]{2}{*}{ Age (wks) } & \multicolumn{2}{|c|}{ Sudani } & \multicolumn{2}{|c|}{ Domiaty } & & \multicolumn{4}{|c|}{$(p \leq 0.05)$} \\
\hline & Female & Male & Female & Male & $\begin{array}{l}\text { Over } \\
\text { all age }\end{array}$ & s & sx & a & $A^{\star} S^{\star} S X$ \\
\hline 4 & $5.28 \pm 0.08$ & $5.80 \pm 0.04$ & $5.61 \pm 0.02$ & $5.55 \pm 0.05$ & $5.56^{c}$ & NS & 0.05 & .002 & NS \\
\hline 8 & $5.79 \pm 0.06$ & $6.95 \pm 0.08$ & $6.44 \pm 0.03$ & $6.74 \pm 0.03$ & $6.48^{b}$ & & & & \\
\hline 12 & $6.52 \pm 0.04$ & $7.41 \pm 0.01$ & $6.89 \pm 0.01$ & $7.18 \pm 0.01$ & $7.00^{a}$ & & & & \\
\hline Overall sex & $5.86^{b}$ & $6.72^{\mathrm{a}}$ & $6.31^{b}$ & $6.49^{a}$ & & & & & \\
\hline Overall strain & & & & 40 & & & & & \\
\hline
\end{tabular}

Table 4. Mean \pm SE of keel length $(\mathrm{cm})$ for both sudani and domyati ducks.

\begin{tabular}{|c|c|c|c|c|c|c|c|c|c|}
\hline \multirow{2}{*}{$\begin{array}{c}\text { Age } \\
\text { (week) }\end{array}$} & \multicolumn{2}{|c|}{ Sudani } & \multicolumn{2}{|c|}{ Domiaty } & \multirow{2}{*}{$\begin{array}{c}\text { Overall } \\
\text { age }\end{array}$} & \multicolumn{4}{|c|}{$(p \leq 0.05)$} \\
\hline & Female & Male & Female & Male & & $\mathrm{s}$ & $s x$ & A & $A^{*} S^{*} S X$ \\
\hline 4 & $5.29 \pm 0.03$ & $5.71 \pm 0.03$ & $4.28 \pm 0.01$ & $4.40 \pm 0.34$ & $4.92^{c}$ & NS & 0.02 & 0.0001 & NS \\
\hline 8 & $6.93 \pm 0.05$ & $7.89 \pm 0.01$ & $8.55 \pm 0.48$ & $8.76 \pm 0.49$ & $8.3^{b}$ & & & & \\
\hline 12 & $8.72 \pm 0.02$ & $10.24 \pm 0.06$ & $10.50 \pm 0.06$ & $11.05 \pm 0.09$ & $10.13^{a}$ & & & & \\
\hline Overall sex & $6.98^{\mathrm{b}}$ & $7.95^{\mathrm{a}}$ & $7.96^{\mathrm{b}}$ & $8.07^{\mathrm{a}}$ & & & & & \\
\hline Overall strain & \multicolumn{2}{|c|}{7.46} & \multicolumn{2}{|c|}{7.92} & & & & & \\
\hline
\end{tabular}

\section{Breast circumstances measurements}

Table (5) showed that age, sex, and strain affected significant breast circumstances which Breast circumferences of domyati strain exceeded significantly of their sudani counterparts, also sudani and domyati males were higher significant than sudani and domyati females, although domyati male higher than sudani male, also domyati female higher than sudani female. Fattouh (1994) stated the superiority of breast circumferences from 8 to 20 weeks of age in males than females. Similar results in breast circumferences were reported by El-Tehiti (2001), Ali (2005), Ayman (2005)

Table 5. Mean \pm SE of Breast circumference $(\mathrm{cm})$ for both sudani and domyati ducks.

\begin{tabular}{|c|c|c|c|c|c|c|c|c|c|}
\hline \multirow{2}{*}{$\begin{array}{c}\text { Age } \\
\text { (wks) }\end{array}$} & \multicolumn{2}{|c|}{ Sudani } & \multicolumn{2}{|c|}{ Domiaty } & \multirow{2}{*}{$\begin{array}{c}\text { Overall } \\
\text { Age }\end{array}$} & \multicolumn{4}{|c|}{$(p \leq 0.05)$} \\
\hline & Female & Male & Female & Male & & $S$ & SX & $A$ & $A * S * S X$ \\
\hline 4 & $15.08 \pm 0.17$ & $16.28 \pm 0.27$ & $17.38 \pm 0.30$ & $17.36 \pm 0.49$ & $16.53 c$ & 0.0001 & 0.04 & 0.0001 & NS \\
\hline 8 & $20.00 \pm 0.17$ & $21.98 \pm 0.43$ & $26.65 \pm 0.64$ & $26.75 \pm 0.44$ & $23.85^{b}$ & & & & \\
\hline 12 & $26.55 \pm 0.55$ & $29.95 \pm 0.65$ & $30.75 \pm 0.39$ & $31.45 \pm 0.29$ & $29.68^{a}$ & & & & \\
\hline Overall sex & $20.54^{b}$ & $22.74^{\mathrm{a}}$ & $24.93^{b}$ & $25.19^{a}$ & & & & & \\
\hline Overall strain & 21. & $64^{b}$ & 26. & $.06^{\mathrm{a}}$ & & & & & \\
\hline
\end{tabular}

\section{Genetic microsatellite parameters}

The Table (6 and 7) appear that the PIC of the microsatellite AY493338 and APHO1 in the Sudany duck was the medium $(\mathrm{PIC}=0.55 ; 0.54$ re- spectively), but PIC of the microsatellite AY493338 and $\mathrm{APHO} 1$ in Domiaty duck was lowest $(\mathrm{PIC}=$ $0.41 ; 0.32$ respectively), the locus AJ272578, SMO1 and Oxy14 have the lowest PIC in both Sudany and Domiaty ducks. The average PIC of all 

of ducks: Sudani and Domyati

sites was 0.35 and 0.32 in Sudany and Domiaty populations. The last results appear that the PIC of most microsatellite sites was lower than 0.5 . This indicated that the selected microsatellite loci had 1ow diversity and can reflect the genetic relationship among Sodany and Domiaty populations of near populations on a molecular level.While, the mean number of alleles per locus were 4.9and 4.7 for Sodany and Domiaty populations respectively. The number of alleles identified at each locus for each population is considered to be a good indicator of genetic variability (Khan Ahmadi et al 2007).

The maximum observed heterozygosity values were found for AJ272579 and APHO1 loci in both Sudany and Domiaty ducks populations. The low mean heterozygosity might be credited to the low number of alleles exhibit in the population, abnormal state of inbreeding values in light of little successful populace measure associated with rearing rushes. Alternate components can likewise cause an absence of heterozygotes in a populace (Jordana et al 2000). To begin with, the locus can be under determination, the hereditary bumming a ride impact with some morphological or gainful qualities of specific intrigue. Second, invalid alleles (nonamplifying alleles) may be introduce which prompt a bogus perception of overabundance homozygotes. Third, the nearness of populace substructure may prompt Wahlund's impact.

Table 6. Illustrate Microtallites primers features.

\begin{tabular}{|c|l|l|}
\hline $\begin{array}{c}\text { Primer } \\
\text { codes }\end{array}$ & \multicolumn{1}{|c|}{ Forward sequence } & \multicolumn{1}{|c|}{ Reverse sequence } \\
\hline AY493338 & ACAGCTTCAGCAGACTTAGA & GCAGAAAGTGTATTAAGGAAG \\
AY493294 & TTAGTAAACTCTTGCCATCT & TGTAGTTTAGTTGCTGGATA \\
AJ272577 & CACTTGCTCTTCACTTTCTTT & GTATGACAGCAGACACGGTAA \\
AJ272578 & AACCAAGACAGAATAATCCTTA & GAACACAACTGCTTTGCTA \\
AJ272579 & ACATCTTTGGCATTTTGAA & CATCCACTAGAACACAGACATT \\
AJ515900 & CCGTCAGACTGTAGGGAAGG & AAAGCTCCACAGAGGCAAAG \\
SMO1 & CTTAAGGTATTGTGCTTTATA & TGGTCCAAAGGGTGTTCTGAGAA \\
APHO1 & TACCTTGCTCTTCACTTTCTT & GTATGACAGCAGACACGGTAA \\
APHO9 & GGATGTTGCCCCACATATTT & TTGCCTTGTTTATGAGCCATTA \\
Oxy14 & GGAAACAGCTATGACCATCCACTACATGGGCATC & GTTATGGCTCATGGGGAAAAAC \\
Oxy1 & CAGTCGGGCGTCATCAGTGGGTTAGATGGATG & GTTTCCTGCCACATCCCCTCAT \\
\hline
\end{tabular}

Table 7. Polymorphic information content (PIC), expected heterozygosity $(\mathrm{He})$, Observed heterozygosity $(\mathrm{HO})$ and number of alleles of Domyati and Sudani breeds duck.

\begin{tabular}{|c|c|c|c|c|c|c|c|c|}
\hline \multirow{2}{*}{$\begin{array}{c}\text { Primer } \\
\text { codes }\end{array}$} & \multicolumn{2}{|c|}{ PIC } & \multicolumn{3}{c|}{ He } & \multicolumn{2}{c|}{ HO } & \multicolumn{2}{c|}{ Na } \\
\cline { 2 - 8 } AY493338 & Sodany & Domiaty & Sodany & Domiaty & Sodany & Domiaty & Sodany & Domiaty \\
AY493294 & 0.55 & 0.41 & 0.23 & 0.21 & 0.20 & 0.19 & 2 & 2 \\
AJ272577 & 0.32 & 0.24 & 0.23 & 0.22 & 0.25 & 0.21 & 5 & 6 \\
AJ272578 & 0.21 & 0.30 & 0.27 & 0.20 & 0.24 & 0.18 & 4 & 3 \\
AJ272579 & 0.34 & 0.33 & 0.22 & 0.18 & 0.20 & 0.19 & 5 & 6 \\
AJ515900 & 0.44 & 0.40 & 0.21 & 0.25 & 0.26 & 0.22 & 7 & 7 \\
SMO1 & 0.23 & 0.25 & 0.20 & 0.21 & 0.19 & 0.18 & 3 & 5 \\
APHO1 & 0.54 & 0.32 & 0.30 & 0.28 & 0.25 & 0.22 & 4 & 3 \\
APHO9 & 0.32 & 0.42 & 0.24 & 0.24 & 0.25 & 0.21 & 7 & 6 \\
Oxy14 & 0.24 & 0.32 & 0.21 & 019 & 0.22 & 0.17 & 8 & 8 \\
Oxy1 & 0.30 & 0.29 & 0.23 & 0.18 & 0.25 & 0.19 & 3 & 3 \\
Average & 0.35 & 0.32 & & & & & 4.9 & 4.7 \\
\hline
\end{tabular}

$\mathrm{PIC}=$ polymorphic information content

$\mathrm{He}=$ Expected heterozygosity

$\mathrm{HO}=$ Observed heterozygosity

$\mathrm{Na}$, number of alleles 


\section{REFERENCE}

Ali, K.A.A. 2005. Studies on some factors affecting duck production. Ph.D. Thesis, Fac. Agric, Cairo Univ,, Egypt. pp.45-64,

Ali, K.A.A. 2000. Effect of some environmental factors affecting ducks performance. M.Sc. Thesis. Fac. Agric., Ain Shams Univ., Cairo, Egypt, pp. 55-75.

Awad A.; Ghonim A.I.A. and Fattouh M.H.A. 2014. Effect of Force Molting On Productive Performance of Sudani Ducks Egypt. Poult. Sci., 34 (IV), 925-938.

Awad, A.L., Ghonim A.I.A., M.H.A Fatouh and Soliman, M.F. 2013.Effect of supplementing some growth promoters to duckling diets on growth performance and carcass traits under summer conditionofDomyati ducks. Egypt Poult. Sci., 28,1115 -1136

Awad, A. L., Ghonim M. A.A., Kasim A.I.A.; Hussein M.G. and Humoda I.S.A. 2009. Effect of using rice bran in Domyati ducklings diets on growth performance and carcass quality. Poult. Sci., 29(1), 173 -189

Ayman, R.G. 2015. Genetic Characterization of local and exotic duck strains and evaluation of their productive and reproductive traits under Egyptian conditions. M.Sc. Institute of African Research and Studies, Cairo Univ., Giza, Egypt, pp. 47-75.

Botstein, D., White, R.L., Skolnick M. and Davis R. W.. 1980. Construction of a genetic linkage map in man using restriction fragment length polymorphisms. The American Journal of Human Genetics 32, 314-331.

El-Sayed, T.M. 1979. Genetically and nutritional studies on ducks. (A comparison study between the effect of genetic and nutrition on improving some productive traits of white Pekin ducklings M.Sc. Thesis, Fac. of Agric., Tanta University, Tanta, Egypt, pp. 49-61.

El-Tehiti, A.I.A. 2001. Water pollution and its effect on some productive traits in ducks M.Sc. Thesis Fac. Agric., Ain Shams Univ.. Cairo, Egypt, pp. 43-57.

Farghaly, M. and Asar M.A., 1988. Effect of age, sex and calorie/protein ratio on growth and carcass traits in the ducks. Egypt. Poultry Sci. 8, 296-311.
Fattouh, M .H.A. 1994. A study for some production traits in ducks. M.Sc. Thesis. Fac. Agric., Mansoura Univ., Mansoura, Egypt, pp. 50-65.

Hedrick, P.W., 1999. Highly variable loci and their interpretation in evolution and conservation. International Journal of Organic Evolution, 53(2), 313-318.

Jordana, J., Folch P. and Aranguren A., 2000. Microsatellite analysis of genetic diversity in the Catalonian donkey breed. J. Anim. Breed. Genet., 118, 57-63.

Khan Ahmadi A. and Vafaei G.A.H., 2007. Microsatellite Analysis of Genetic Diversity in Pekin (Anas platyrhynchos) and Muscovy (Cairina moschata) Duck Populations. International Journal of Poultry Science 6 (5), 378-382.

Kout Elkloub, Moustafa M. El.; Awad A.L. and Ghonim A.I.A. 2010. Response of Domyati ducklings to diets containing different levels of metabolizable energy and crude protein: 1During growth period . Egypt Poult. Sci., 30, 535-564.

Maak S, Wimmers K, Weigend S, Neumann K. 2003. Isolation and microsatellites developed for the Peking duck (Anas platyrhynchos), Anim. Genet. 31, 228-241.

Maak, S., K. Neumann, G. von Lengerken and R. Gattermann, 2000 First seven microsatellites developed for the Peking $\operatorname{duck}($ Anas platyrhynchos). Anim. Genet. 31, 233.

Nestor, K.E; Bacon W.L.; Saif Y.M. and Renner Y.M. 1985. The influence of genetic increase in shank on body weight, walking ability and reproduction of turkeys. Poultry. Sci, 64, 22482255.

Qiu, N., Ma M., Cai Z., Jin Y., Huang X., Q. Huang, and Sun S.2012. Proteomic analysis of egg white proteins during the early phase of embryonic development. J. Proteomics. 75,1895-1905.

SAS, 2001. SAS User s Guide: Statistical Analysis System Inst., Inc., Cary, Nc. USA.

Schmidt, G.S., Filho, P.H., Figueiredo, E.A.P. and Coutinho, L.L. 2000. Using DNA fingerprinting for body weight selection in broiler lines. British Poultry Science. 41, suppS32S33.

Xiao, W. 2002. Study the genetic diversity of Chinese native pigs using blood protein polymorphism. Ph.D Thesis, China Agricultural University, China, pp. 77-78. 


$$
\text { المؤتمر الرابع عشر لبحوث التنمية الزراعية، }
$$

دراسة مقارنة على بعض الصفات الانتاجية والتتوصيف الوراثى لسلالاتين من البط المحلى

$$
\text { (السودانى والدمياطى) }
$$

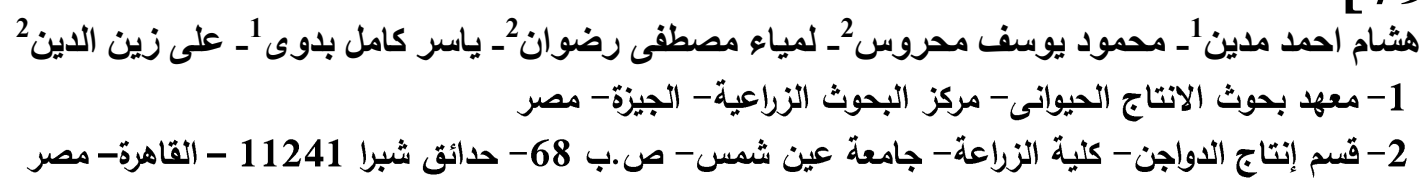

*Corresponding author: Lamia_radwan@agr.asu.edu.eg

Received 9 September, 2018, $\quad$ Accepted 2 October, 2018

الدمياطى. عند عمر (4) اسابيع متوسط وزن الجسم لسلالة السودانى 617.21 بينما كانت 446.38 لسلالة الدمياطى. عند عمر (8) اسابيع متوسط وزن كاني الجسم لسلالة السودانى 1490.90 بينما كانت 1235.98 لسلالة- الدمياطى. عند عمر (12) اسابيع متوسط وزن الجسم لسلالة السودانى 2211.0

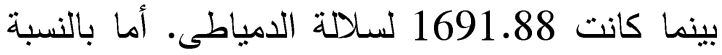
لصفة مقاييس الجسم (طول عظمة الساق- طول

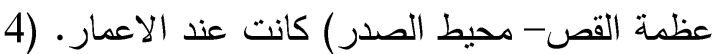

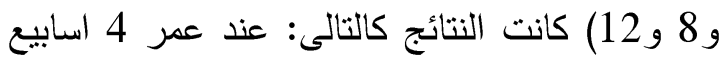
لم تكن هناك ایى فروق معنوية بين السلالتين. عند

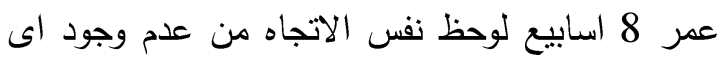
فروق معنوية بين السلالتين. عند عمر 12 اسبوع الأجن ظهرت الفروق المعنوية بين السلالتين لصفة محيط الصدر فقط حيث كان التفوق فى صالح السلالة الدمياطى. أما الدراسات الوراثية التى تمت باستخدام التقنيات الوراثية الحديثة مثل المايكروستالايت فقط التط اظهرت ان هناك تقاربا وراثيا بين كلا السلالتين موضع التحاني

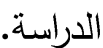

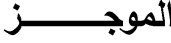

تستهدف هذه الدراسة دراسة الاداء الانتاجى

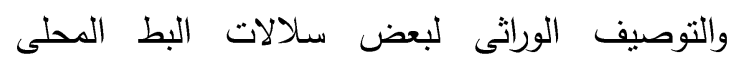

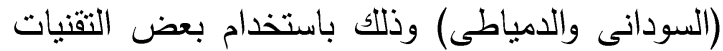
الوراثية الحديثة (مثل المايكروستالايت).بدأت الدراسة باستة باستخدام 50 كتكوت سن يوم من كلا السلالثنين وتمت التهات التربية تحت نفس الظروف والرعاية حتى عمر التسويق 12 اسبوع، واستخدم نوعين من العلائق : عليقة بادئ الفئ (من-4-4 اسبوع) و عليقة ناهى (من 5-12-12 اسبوع)

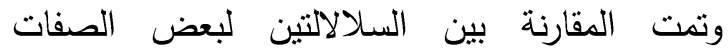
الانتاجية وكانت اهم المقاييس الانتاجية التى تم تنتاولها

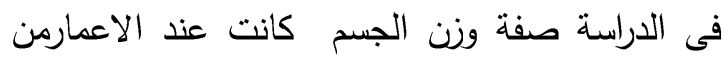

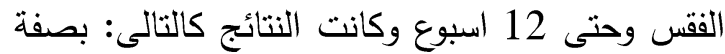
عامة كانت اوزان متوسطات الجسم لسلالة السودانى

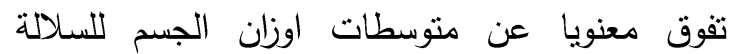
الاخرى (الدمياطى). عند الفقس متوسط وزن الجسم لسلالة السودانى 40.80 بينما كانت 34.12 لسلالة الإنة 